\title{
The Assessment of the Effect of Changes in Lung Cancer Follow-up Period on the Quality of Life Using EQ-5D Questionnaire and Follow Data (AKAYAK-1 Multicenter Project)
}

\author{
Ahmet E. ERBAYCU ${ }^{1}$, Tuncay GOKSEL ${ }^{2}$, Erhan ESER ${ }^{3}$, Kader K. GURSUL ${ }^{1}$, Burcu BASARIK ${ }^{2}$, \\ Aysen $\mathrm{OZ}^{4}$, Pinar CELIK ${ }^{4}$, Ebru C. EDIZ ${ }^{5}$, Osman HATIPOGLU ${ }^{5}$, Bedriye A. YAYLA ${ }^{6}$, \\ Sevin BASER ${ }^{6}$, Hakan BAYDUR ${ }^{3}$
}

\footnotetext{
${ }^{1}$ Izmir Dr. Suat Seren Chest Diseases and Thoracic Surgery Training and Research Hospital, Department of Chest Diseases, Izmir

${ }^{2}$ Ege University, Faculty of Medicine, Department of Chest Diseases, Izmir

${ }^{3}$ Celal Bayar University, Faculty of Medicine, Department of Public Health, Manisa

${ }^{4}$ Celal Bayar University, Faculty of Medicine, Department of Chest Diseases, Manisa

${ }^{5}$ Trakya University, Faculty of Medicine, Department of Chest Diseases, Edirne

${ }^{6}$ Pamukkale University, Faculty of Medicine, Department of Chest Diseases, Denizli, TURKEY
}

\begin{abstract}
The EURO-QOL (EQ-5D), a generic quality of life measure, is a self-report scale. The aim was to study the reliability, validity and feasibility of the Turkish version of the EQ-5D as an instrument to evaluate quality of life in lung cancer patients in Turkish society. A prospective cohort study carried out within the framework of the multicenter Lung Cancer Association Project which was conducted in collaboration with Turkish Thoracic Society, Lung and Pleural Malignancies working group and Health and Quality of Life Society. A total of 266 patients were included in the study with a mean age of 61.3 years. $75,9 \%$ of the patients had chemotherapy alone; $9 \%$ received sequential chemotherapy and radiotherapy, 8,6\% were given concurrent chemotherapy and radiotherapy, and 6,4\% of them received radical radiotherapy alone. EQ-5D score measures at the moment of diagnosis were found to be moderately reliable while measures at the 3rd chemotherapy cycle, 5th chemotherapy cycle and after the radiotherapy were highly reliable. The items of the EQ-5D were found to be consistent among themselves. EQ-5D Visual Analogue Scale scores at diagnosis, the 3rd cycle, the 5th cycle and following radiotherapy were assessed to be correlated with each other. EQ-5D scale was found to be valid as it meets the conditions of 6 fit indices in our study design. The psychometric properties of the Turkish version of the EQ-5D questionnaire is a valid and reliable scale for patients with lung cancer in Turkey and it can be safely used in clinical practices.
\end{abstract}

Keywords: Lung cancer, Quality of life, EQ-5D, EQ-5D Visual Analogue Scale, Validity

ÖZET

Akciğer Kanserli Hastalarda İzlem Sürecindeki Değişikliklerin Yaşam Kalitesine Etkisinin EQ-5D Ölçeği ve Takip Sonuçları ile Değerlendirilmesi (AKAYAK-1 Çok Merkezli Proje)

EURO-QOL (EQ-5D) genel yaşam kalitesi ölçeği bir öz-bildirim ölçeğidir. Amaç Türk toplumunda akciğer kanserinde yaşam kalitesi değerlendirme aracı olarak EQ-5D'nin Türkçe sürümünün güvenilir, geçerli ve uygulanabilir olup olmadığının araştırımasıdır. Türk Toraks Derneği, Akciğer ve Plevra Maligniteleri Çalışma Grubu ile Sağlıkta Yaşam Kalitesi Derneğinin ortaklaşa yürüttüğü çok merkezli Akciğer Kanserinde Yaşam Kalitesi Projesi çerçevesinde yürütülen prospektif bir kohort çalışmasıdır. Çalışmaya yaş ortalaması 61.3 yıl olan 266 hasta alındı. Hastaların \%75,9'u sadece kemoterapi; \%9'u ardışık kemoterapi ve radyoterapi, \%8,6'sı eşzamanlı kemoterapi ve radyoterapi, \%6,4'ü sadece radikal radyoterapi almıştı. Tanı anındaki EQ-5D indeks skor ölçümünün orta derecede güvenilir, 3. kemoterapi küründeki ölçüm, 5. kemoterapi küründeki ölçüm ve radyoterapi sonrasındaki ölçümlerin yüksek derecede güvenilir olduğu bulunmuştur. EQ-5D maddelerinin kendi içinde tutarlı olduğu görülmüştür. 
International Journal of Hematology and Oncology

EQ-5D Vizuel Analog Skalası tanı anında, 3. kürde, 5. kürde ve radyoterapi sonrası değerlendirildiğinde birbiri ile korele bulunmuștur. Çalışma modelimizde 6 tane uyum indeksi koşulları yerine getirdiğinden EQ-5D ölçeği geçerli bulunmuştur. EQ-5D genel yaşam kalitesi ölçeğinin Türkçe sürümünün psikometrik özellikleri, Türkiye'deki akciğer kanserli hastalarda geçerli ve güvenilir bir ölçektir ve klinik pratikte güvenle kullanılabilir.

Anahtar Kelimeler: Akciğer kanseri, Yașam kalitesi, EQ-5D, EQ-5D Vizuel Analog Skalası, Geçerlilik

\section{INTRODUCTION}

Quality of life (QOL) is a broad concept that as affected by the individual's physical health, psychological state, beliefs, social relations and relations with the environment in a complicated way. It is a significant measure for the evaluation of the state of health and the effects of treatments. Health related quality of life is associated with how the individual perceives the disease and the functional effects of treatments given. ${ }^{1-4}$

In the assessment of the treatments given, response rate or the length of survival is not a criterion alone in lung cancer. The purpose of the treatment is to attain improvement in life quality and a prolonged survival with the palliation of symptoms. Questioning the quality of life is a significant measure in evaluating the palliative effect of treatment or treatment-associated problems and deciding on the clinical course. ${ }^{5,6}$

Euro QoL (EQ-5D) quality of life scale was developed by the Euro Qol group in 1987 and was translated into more than 60 languages. It is a selfreport scale which evaluates five dimensions with five questions. The questionnaire consists of two sections.

EQ-5D index scale; consist of five dimensions namely; mobility, self-care, usual activities, pain/ discomfort and anxiety/depression. Each item on the scale is assessed on three levels (Likert type). As well as obtaining response distributions of these dimensions; health availability index scores can be calculated. Responses at each dimension have three options: no problems, some problems and major problems. The scale defines 243 possible different health problems. Over the 5 dimensions of the scale, index scores are calculated varying between -0.59 and 1 . In the score function, 0 refers to death, 1 refers to perfect health while negative values show such conditions as unconsciousness and bedridden living etc. For the calculation of scores, index score was calculated using the coefficients produced by Dolan et al. in their study. ${ }^{7,8}$

EQ-5D Visual Analogue Scale (VAS); includes the individuals' responding about their current state of health by referring to a point between 0 and 100 , that is 'the worst imaginable health state' and 'the best imaginable health state'. It is a thermometerlike visual analogue scale. ${ }^{7,8}$

The aim of the present study is to analyze the reliability, validity and feasibility of the Turkish version of the EQ-5D generic quality of life scale as an instrument to evaluate quality of life in lung cancer patients in Turkish society.

\section{PATIENTS AND METHODS}

\section{Scope}

The present study was carried out within the framework of the AKAYAK (Quality of Life in Lung Cancer) Project conducted in collaboration of Turkish Thoracic Society and Turkish Society for Quality of Life Research (SAYKAD). AKAYAK project aimed to reveal the psychometric features (validity and reliability) of the Turkish versions of life quality assessment scales that are developed specifically for lung cancer and are commonly used in lung cancer patients in the world and to show clinical performances of these scales and their sensitivity to changes. It was intended to evaluate the effect of the changes during the follow-up period on the life quality of lung cancer patients observed with EQ-5D scale and follow-up results in five different health centers across Turkey and to investigate whether the Turkish version of the EQ-5D scale is reliable, valid and feasible as a life quality assessment instrument in lung cancer among Turkish society.

Approval was obtained from the Ege University Research Ethics Committee within the scope of the AKAYAK project. All the patients were included 
in the study after reading, understanding and signing the written consent form.

\section{Inclusion Criteria for the Study}

- Stage IIIB or IV cases (including all histological types) diagnosed with primary lung cancer

- Cases that received no previous treatment and are planned to be given chemotherapy (CT), chemoradiotherapy (CRT) or radiotherapy (RT)

- Cases who were literate, could read and fill in the test forms and accepted to participate in the study and to come for examinations

- Cases who signed the written consent form for voluntary participation

\section{Study Type and Design}

The present study is a prospective cohort (observational) study. We contacted 299 LC patients undergoing active treatment from April 2010 to January 2013 in an inpatient setting or at the outpatient clinics of five comprehensive cancer centres in western Turkey. Study data were collected using two questionnaire batteries consisting of the personal disease information form and the EQ-5D generic quality of life form. Patients who accepted to participate in the study and who signed the consent form were included in the evaluations. The personal disease information form was filled in by the researcher on the first visit upon the diagnosis. Later, the EQ-5D questionnaire was filled in by the patient prior to the doctor's examination, following a detailed explanation in an empty and quiet room.

The scale was later responded prior to the 3rd and 5 th chemotherapy cycle by the patients receiving $\mathrm{CT}$ and prior to treatment and 3 weeks after the completion of treatment by those given CRT or RT. This timing was defined according to the period of treatment assessment. ECOG (Eastern Cooperative Oncology Group) scores and Karnofsky performance status were recorded by the doctor during the same visits.

Staging of all the patients with lung cancer was done in accordance with the TNM (Tumor, lymph node, metastasis) classification. Treatments of patients were planned according to their phases and performance status. Accordingly, patients were given CT alone, or simultaneous/consecutive CRT or radical RT. Palliative RT was applied when necessary. In patients with a serum creatinine level of $>1.5 \mathrm{mg} / \mathrm{dl}$, CT was recommended in combination with carboplatin instead of cisplatin.

\section{Follow-up and Response Evaluation}

The patients were included in follow-ups in terms of treatment, response to treatment, toxicity and survival. Treatments given to the patient and the course were recorded. Treatment response was completed according to the Response Evaluation Criteria in Solid Tumors (RECIST) by the researcher, and toxicity information was completed according to the Common Terminology Criteria for Adverse Effects (CTCAE). CT related side effects were recorded after each cycle. In response evaluation, both cycles were given following the CT and one month after the RT.

\section{Statistical Analysis}

The data of the study were analyzed using the Statistical Package for the Social Sciences (SPSS) 19 and Medcalc 9 (Mariakerke, Belgium) programs. Quantitative data were tested for normal distribution with Kolmogorov test; variables showing normal distribution were analyzed using parametric methods while those following a non-normal distribution were analyzed with nonparametric test models. Independent two groups were compared using independent $t$ test and Mann Whitney $\mathrm{U}$ test. Multiple independent groups were compared with each other using Kruskal-Wallis $\mathrm{H}$ test and Oneway Anova, and for the differences between groups, Bonferonni corrected Mann Whitney U and LSD were employed. Dependent two groups were compared with paired $\mathrm{T}$ test and repeated measures Anova tests were used for the comparison of multiple dependent groups. Kendall Tau-b test was used to study the correlations between quantitative data. For the comparison of the categorical data, pearson chi-square, chi-square, Fisher exact and Continuity Correction tests were employed. Kaplan-meier (product limit method) analysis was done to examine the effects of the factors on mortality and survival times. In order to measure the effects of 


\begin{tabular}{|c|c|c|}
\hline Parameters & $\mathbf{n}$ & $\%$ \\
\hline Mean Age (years) & \multirow{2}{*}{\multicolumn{2}{|c|}{$61.35 \pm 9.57(35-86)$}} \\
\hline Gender & & \\
\hline Male & 248 & 93.2 \\
\hline Female & 18 & 6.8 \\
\hline \multicolumn{3}{|l|}{ Education } \\
\hline Primary School & 188 & 70.7 \\
\hline Secondary School & 18 & 6.8 \\
\hline High School & 27 & 10.1 \\
\hline University & 13 & 4.9 \\
\hline None & 20 & 7.5 \\
\hline \multicolumn{3}{|l|}{ Marital Status } \\
\hline Single & 7 & 2.6 \\
\hline Married & 233 & 87.6 \\
\hline Divorced & 8 & 3.0 \\
\hline Widowed & 18 & 6.8 \\
\hline \multicolumn{3}{|l|}{ Occupation } \\
\hline Freelance & 72 & 27.1 \\
\hline Wage-earner & 15 & 5.6 \\
\hline Retired & 160 & 60.2 \\
\hline Unemployed & 19 & 7.1 \\
\hline \multicolumn{3}{|l|}{ Smoking Status } \\
\hline Never smoked & 13 & 4.9 \\
\hline Smoker & 52 & 19.5 \\
\hline Gave up & 201 & 75.6 \\
\hline \multicolumn{3}{|l|}{ Comorbidity } \\
\hline Yes & 94 & 35.3 \\
\hline Hypertension & 27 & 24.5 \\
\hline COPD & 23 & 20.9 \\
\hline Coronary artery disease & 23 & 20.9 \\
\hline Diabetes mellitus & 22 & 20.0 \\
\hline Solid organ tumor & 5 & 4.5 \\
\hline Chronic kidney failure & 3 & 2.7 \\
\hline Peripheral artery disease & 2 & 1.8 \\
\hline Gastric ulcer & 2 & 1.8 \\
\hline Hepatitis B & 2 & 1.8 \\
\hline Hyperthyroidism & 1 & 0.9 \\
\hline No & 172 & \\
\hline
\end{tabular}

prognostic variables on the survival time, Cox Regression analysis was employed. Cut-off values were calculated using ROC (Receiver Operating Curve) curve analysis. Logistic regression test was conducted to determine the cause-effect relations of the nominal response variable with the explanatory variables at dichotomous and multinominal categories.
A "Confirmatory approach" was used in the reliability and validity analyses in the study. In other words, the appropriateness of the questionnaire's construct in its original language was questioned in its Turkish version, and no change in the construct of the questionnaire was allowed. Reliability analysis was carried out through internal consistency and item analysis approaches. Internal consistency was shown with a Cronbach Alfa value. Cronbach Alpha coefficient is between 0 and 1, reliability increases as it approaches 1 , decreases as it approaches 0 . If it is $<0.40$, the scale is not reliable; $0.40-0.60$ shows low reliability; $0.60-0.80$ shows moderate reliability, $>0.80$ refers to high reliability.

Quantitative data are presented in mean \pm standard deviation and median $\pm \mathrm{IQR}$ (Inter quartile range), while categorical data are given in numbers (n) and percentages $(\%)$. The data were examined at a reliability level of $95 \%$, and a p value of over 0.05 was accepted as insignificant, while one under 0.05 was taken as significant.

\section{RESULTS}

After exclusion of incomplete data, a total of 266 patients diagnosed with lung cancer were evaluated (Table 1). There was no asymptomatic patient at the time of diagnosis. Lung cancer specific features and performance score were presented on Table 2. The median ECOG $(1,00)$ and Karnofsky performance score $(90,00)$ were similar according to the tumor cell type (Mann Whitney U Test, p>0.05), except a better ECOG score in small cell lung cancer (SCLC) $(\mathrm{p}=0.027)$.

EQ-5D and EQ-5D VAS scores did not vary by gender, marital status, occupation, smoking status and educational background. In patients with accompanying diseases, EQ-5D and EQ-5D VAS scores were low. EQ-5D score was lower as the age was older (Table 3). EQ-5D was not associated with the tumor stage and tumor cell type. EQ5D VAS score did not vary by tumor cell type and stage (Table 4).

EQ-5D score was higher at the time of diagnosis and was similar in SCLC and non-small cell lung cancer (NSCLC). There was an increase in the EQ- 


\begin{tabular}{|c|c|c|}
\hline Parameters & $\mathbf{n}$ & $\%$ \\
\hline \multicolumn{3}{|l|}{ Tumor cell type } \\
\hline Squamous & 100 & 37.6 \\
\hline Adenocarcinoma & 64 & 24.1 \\
\hline Small cell lung carcinoma & 56 & 21.0 \\
\hline NSCLC (no subgroups spe & ecified) 29 & 10.9 \\
\hline Radiologic lung tumor & 8 & 3.0 \\
\hline Non classified & 5 & 1.9 \\
\hline Large cell & 4 & 1.5 \\
\hline \multicolumn{3}{|l|}{ Tumor stage } \\
\hline Stage IIIB & 86 & 22.3 \\
\hline Stage IV & 180 & 67.7 \\
\hline \multicolumn{3}{|l|}{ Location of Metastasis } \\
\hline Bone & 65 & 29.8 \\
\hline Opposite lung & 36 & 16.5 \\
\hline Adrenal & 34 & 15.6 \\
\hline Brain & 26 & 11.9 \\
\hline Liver & 25 & 11.5 \\
\hline Cervical lymph gland & 16 & 7.3 \\
\hline Abdominal lymph gland & 7 & 3.2 \\
\hline Axillary lymph gland & 6 & 2.8 \\
\hline Skin & 2 & 0.9 \\
\hline Kidney & 1 & 0.5 \\
\hline \multicolumn{3}{|l|}{ Symptoms } \\
\hline Cough & 180 & 67.7 \\
\hline Dyspnea & 147 & 55.3 \\
\hline Weight loss & 145 & 54.7 \\
\hline Loss of appetite & 122 & 45.9 \\
\hline Localized pain & 118 & 44.4 \\
\hline Pain in the chest & 103 & 38.7 \\
\hline Aphonia & 55 & 20.7 \\
\hline Hemoptysis & 54 & 20.3 \\
\hline Fever & 28 & 10.5 \\
\hline Neurologic symptoms & 24 & 9.0 \\
\hline $\begin{array}{l}\text { Vena cava superior } \\
\text { syndrome }\end{array}$ & 11 & 4.1 \\
\hline Horner syndrome & 2 & 0.8 \\
\hline \multicolumn{3}{|l|}{ Type of Treatment } \\
\hline Chemotherapy & 202 & 75.9 \\
\hline $\begin{array}{l}\text { Chemotherapy + } \\
\text { Radiotherapy (Consecutiv }\end{array}$ & $\begin{array}{l}24 \\
\text { ee) }\end{array}$ & 9.0 \\
\hline $\begin{array}{l}\text { Chemoradiotherapy } \\
\text { (Simultaneous) }\end{array}$ & 23 & 8.6 \\
\hline Radical Radiotherapy & 17 & 6.4 \\
\hline \multicolumn{3}{|l|}{ Treatment Response } \\
\hline Complete & 5 & 7.1 \\
\hline Partial & 43 & 61.4 \\
\hline Stable & 9 & 12.9 \\
\hline Progression & 13 & 18.6 \\
\hline CLC: Non small cell lung & cer & \\
\hline
\end{tabular}

5D and EQ-5D VAS scores of SCLC patients while a change in the form of a decrease was present in NSCLC patients (EQ-5D Index score change, $p=$
0.036) (EQ-5D VAS change, $p=0.049$ ). The final EQ-5D and EQ-5D VAS scores of SCLC patients are higher than those of NSCLC patients. In responses given at diagnosis to each item; no / some / major problems were present for mobility $(62.8 \%, 30.5 \%, 6.8 \%)$, self care $(81.2 \%, 16.2 \%$, $2.6 \%)$, usual activities $(57.1 \%, 25.6 \%, 17.3 \%)$, pain / discomfort $(43.6 \%, 45.9,10.5 \%)$ and anxiety / depression $(67.3 \%, 29.7 \%, 3.0 \%)$.

When the correlations among the changes in EQ5D, EQ-5D VAS, ECOG and Karnofsky scores were evaluated; a negative correlation was found between difference ECOG and difference Karnofsky (high correlation), difference EQ-5D (moderate correlation) and difference EQ-5D VAS (moderate correlation). That is, if difference ECOG had a (-) value, difference Karnofsky, difference EQ5D and difference EQ-5D VAS had (+) values. Difference Karnofsky was found to have a positive correlation with difference EQ-5D (high correlation) and difference EQ-5D VAS (moderate correlation). In other words, if difference Karnofsky had a (+) value, difference EQ-5D and EQ-5D VAS had $(+)$ values as well.

There was a positive correlation between difference EQ-5D VAS and difference EQ-5D (high correlation), and if difference EQ-5D VAS had a (+) value, difference EQ-5D had a (+) value as well. All the correlations among the changes in EQ-5D, EQ-5D VAS, ECOG and Karnofsky scores were significant $(\mathrm{p}=0.000)$.

When a cut off value for mortality was intended according to EQ-5D change and EQ-5D VAS change; difference EQ-5D cut-off was -0.79 . Sensitivity was $75 \%$, specificity was $98.4 \%$ and the area under the curve was $0.793 \pm 0.091(\mathrm{p}=0.001)$. Difference EQ-5D VAS cut-off was -0.30, with sensitivity $75 \%$, specificity $84,3 \%$ and the area under the curve $0.730 \pm 0.11(\mathrm{p}=0.035)$.

When the effect of EQ-5D and EQ-5D VAS score changes on survival according to the cut off value specified for mortality was examined (Cox Regression - Backward Stepwise (Wald) Model), it was 31,732 times higher in exitus patients with EQ-5D change values of $[\leq-0.79]$ than surviving patients $(p=0.001)$. It was 4.630 times higher in exitus patients with EQ-5D VAS change values of $[\leq-0.30]$ 
International Journal of Hematology and Oncology

Table 3. EQ-5D Index Score and Eq-5d Vas Score according to socio-demographic data

\begin{tabular}{|c|c|c|c|c|c|c|c|}
\hline & & \multicolumn{2}{|c|}{ EQ-5D Index Score } & \multirow[t]{2}{*}{ p } & \multicolumn{2}{|c|}{ EQ-5D VAS Score } & \multirow[t]{2}{*}{$\mathbf{p}$} \\
\hline & & Mean & SD & & Mean & SD & \\
\hline \multirow[t]{2}{*}{ Gender } & Male & 0.66 & 0.36 & 0.567 & 66.52 & 20.68 & 0.272 \\
\hline & Female & 0.71 & 0.32 & & 63.89 & 20.40 & \\
\hline \multirow[t]{2}{*}{ Marital Status } & Single & 1.72 & 1.26 & 0.07 & 186.73 & 65.07 & 0.14 \\
\hline & Married & 0.68 & 0.34 & & 67.23 & 20.61 & \\
\hline \multirow[t]{4}{*}{ Occupation } & Freelance & 0.61 & 0.35 & 0.226 & 66.81 & 20.51 & 0.251 \\
\hline & Wageworker & 0.82 & 0.31 & & 76.00 & 18.34 & \\
\hline & Retired & 0.66 & 0.37 & & 65.66 & 21.22 & \\
\hline & Unemployed & 0.68 & 0.34 & & 62.63 & 16.61 & \\
\hline \multirow[t]{3}{*}{ Smoking Status } & Never smoked & 0.66 & 0.35 & 0.665 & 63.85 & 17.70 & 0.2 \\
\hline & Smoker & 1.44 & 0.61 & & 142.77 & 35.24 & \\
\hline & Gave up & 0.65 & 0.37 & & 65.07 & 21.42 & \\
\hline \multirow[t]{5}{*}{ Graduation } & Primary & 0.64 & 0.36 & 0.534 & 66.93 & 20.41 & 0.706 \\
\hline & Secondary & 0.79 & 0.22 & & 61.76 & 19.03 & \\
\hline & High School & 0.65 & 0.40 & & 65.07 & 25.28 & \\
\hline & University & 0.78 & 0.31 & & 71.15 & 19.06 & \\
\hline & None & 0.64 & 0.42 & & 63.33 & 19.10 & \\
\hline \multirow[t]{2}{*}{ Comorbidity } & Yes & 0.60 & 0.41 & 0.049 & 61.85 & 20.69 & 0.008 \\
\hline & No & 0.69 & 0.33 & & 68.81 & 20.24 & \\
\hline \multirow[t]{7}{*}{ Age } & $<40=A$ & 0.82 & 0.16 & 0.049 & 61.67 & 29.30 & 0.007 \\
\hline & {$[40-49]=\mathrm{B}$} & 0.74 & 0.35 & & 60.71 & 20.99 & \\
\hline & {$[50-59]=\mathrm{C}$} & 0.71 & 0.34 & & 71.05 & 20.26 & \\
\hline & {$[60-69]=D$} & 0.66 & 0.34 & & 67.45 & 19.81 & \\
\hline & $>=70=\mathrm{E}$ & 0.54 & 0.41 & & 59.05 & 20.23 & \\
\hline & & \multirow{2}{*}{\multicolumn{3}{|c|}{$P(B-E)=\mathbf{0 . 0 2 8} \mathbf{8}^{\star} P(C-E)=\mathbf{0 . 0 0 6}$}} & $P(B-C)=$ & \multirow{2}{*}{\multicolumn{2}{|c|}{$P(C-E)=\mathbf{0 . 0 0 1}$}} \\
\hline & & & & & $P(D-E)=$ & & \\
\hline \multicolumn{2}{|l|}{ OVERALL } & 0.66 & 0.36 & & 66.34 & \multicolumn{2}{|l|}{20.64} \\
\hline
\end{tabular}

in comparison with surviving patients $(\mathrm{p}=0.037)$. EQ-5D change was a more significant risk factor than EQ-5D VAS change.

When EQ-5D changes were grouped as (-), 0 and $(+)$ values and the risk factors affecting change were evaluated (logistic regression - enter model); tumor cell type, ECOG and Karnofsky performance score changes determined the change in EQ-5D scores significantly. In NSCLC patients, the number of patients with a negative difference EQ-5D value was 3.035 times higher than the number of positive patients. In patients with positive difference ECOG values, the number of patients with a negative difference EQ-5D value was 3.030 times higher than the number of positive patients. In patients with negative difference Karnofsky scores, the number of patients with a negative difference EQ-5D value was 1.096 times higher than the number of positive patients.

When EQ-5D VAS score changes were grouped as (-), 0 and (+) values and the risk factors affecting change were evaluated; smoking, ECOG and Karnofsky score changes determined the change in EQ-5D VAS significantly.

In smokers, the number of patients with a negative difference EQ-5D VAS value was 4.643 times higher than the number of positive patients. In those with a positive difference ECOG value, 


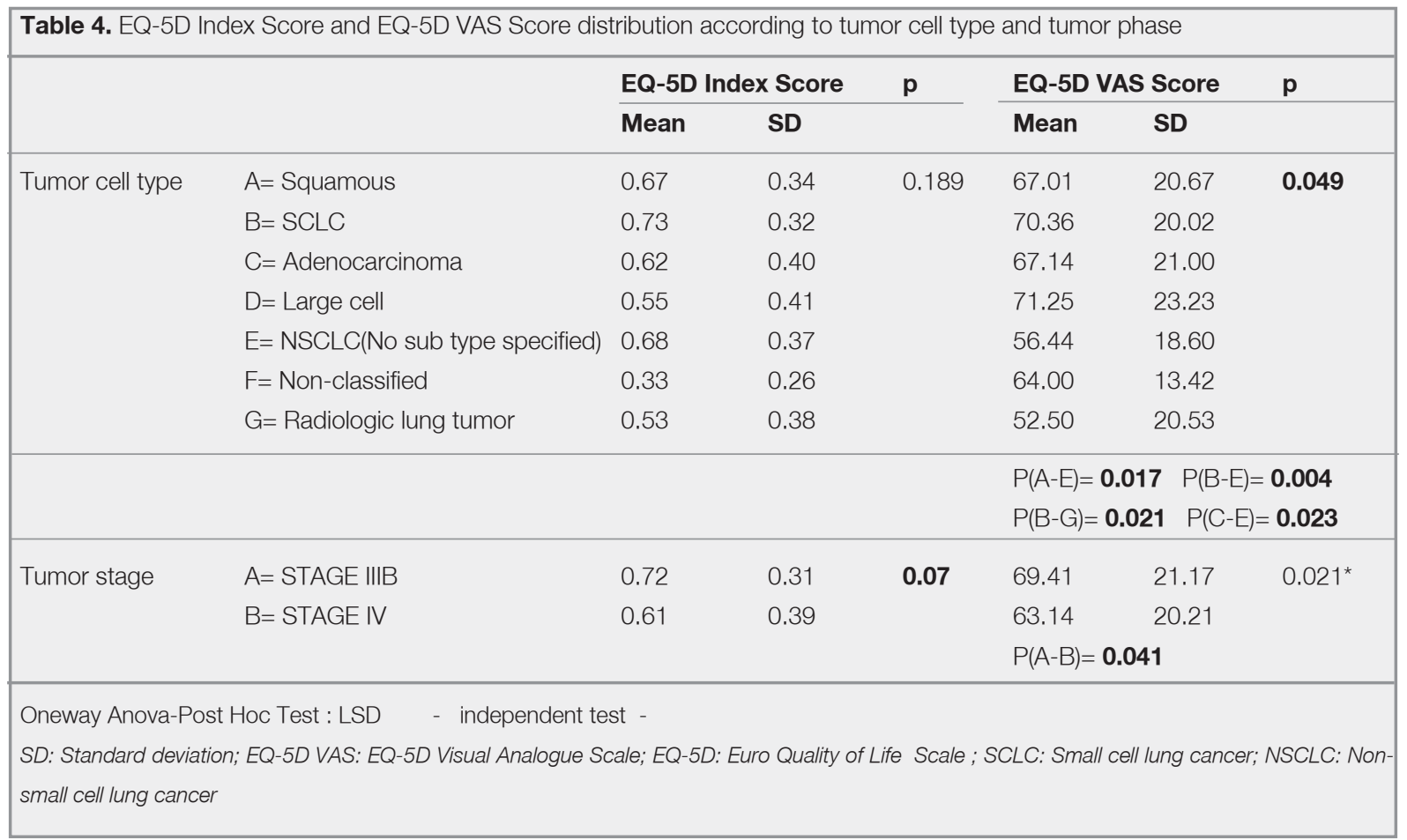

the number of patients with a negative difference EQ-5D VAS value was 2.336 times higher than the number of positive patients. In patients with negative difference Karnofsky values, the number of patients with a negative difference EQ-5D VAS value was 1.074 times higher than the number of positive patient difference.

EQ-5D was moderately reliable in the questionnaire at the time of diagnosis while it was highly reliable in the questionnaires given at the 3rd cycle, 5th cycle and following the RT. At diagnosis, the 3rd cycle, the 5th cycle and following the RT, in each item excluded, the new Cronbach alpha value did not go up only except anxiety/depression. The overall Cronbach alpha was $0.791,0.838,0.87$ and 0.943 in first visit, 3rd cycle, 5 th cycle and following RT. All the items on the scale gave significant correlations with their own dimensions. There was a significant correlation between EQ-5D VAS scores of diagnosis- 3rd cycle, diagnosis-post RT and 3rd cycle- 5th cycle $(\mathrm{p}=0.000)$. Since the expected and observed correlations between the items are in compliance with each other, EQ-5D scale was found to be reliable. Confirmatory factor analysis was carried out to test validity (Figure 1).
The 5 items of the scale were tested for compliance with a single factor and this model was developed for initial values only. In the other repeating questionnaires (during the 3 rd cycle, during the 5th cycle, following RT), the model could not be calculated due to lack of data.

The comparative fit index (CFI) showed good fit 0.964 and the normed fit index (NFI) showed excellent fit 0.954 . Chi-square fit index 20.819 was not in an acceptable range. The goodness fit index (GFI) showed good fit 0.971 and the adjusted goodness fit index (AGFI) gave good fit 0.913 as well.

The root mean square error of approximation (RMSEA) was 0.109 , which was not in an acceptable range. The root mean square error (RMSE) was 0.015 and showed excellent fit. Akaike Information Criterion (CAIC) was desired to be lower than the model compared. CAIC was 6.654, which was lower than the model of comparison (98.752). In general, it was acceptable that at least 3 fit indexes meet the conditions in a confirmatory analysis. Since 6 fit indexes (CFI, NFI, GFI, AGFI, RMR, CAIC) met the required conditions in the study model, EQ-5D scale was found to be valid. 


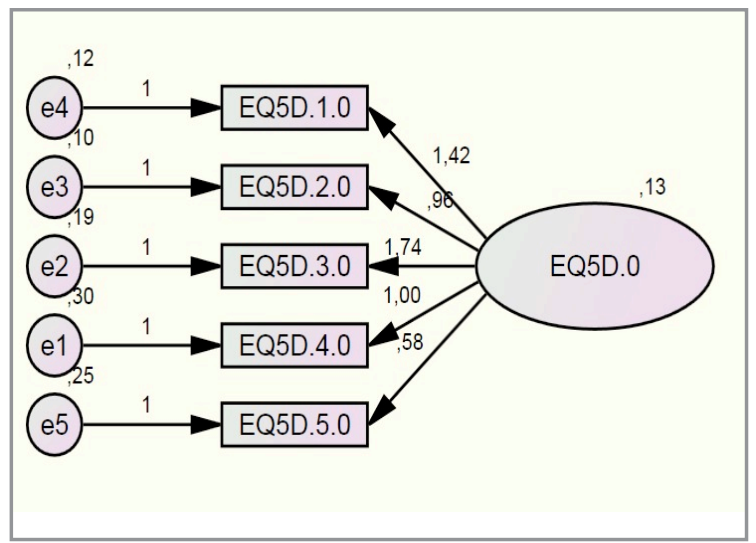

Figure 1. Confirmatory Factor Analysis for the EQ-5D Generic Quality of Life Scale

\section{DISCUSSION}

One of the most striking results came up in the studies carried out on life quality in lung cancer is that the initial quality of life score is the strongest and the most independent prognostic factor in survival. It is also particularly highlighted that one of the finalizing points of treatment studies is the quality of life. Symptom palliation must be the major priority for these patients who are not expected to have an extended survival. ECOG and Karnofsky evaluations which are frequently used in this field could provide an overall opinion, but quality of life measurements is much more comprehensive than these evaluations. ${ }^{5}$

Besides the cancer specific measures such as EORTC QLQ-C30 (European Organization For Research and Treatment of Cancer Quality of Life Questionnaire Core 30) and FACIT (the Functional Assessment of Chronic Illness Therapy), EQ-5D scale is also employed in clinical studies carried out in the field of oncology today. EQ-5D is a scale which reveals health indirectly and can produce index based brief scores. ${ }^{9,10}$

Studies generally report that EQ-5D and EQ-5D VAS scores are directly related with ECOG stages. ${ }^{9}$ In this respect, we found a similar relation in our study. The change in the ECOG and Karnofsky scoring following the treatment was found to be correlated with the change in the EQ-5D and EQ-5D VAS scores after treatment. In lung cancer patients with accompanying diseases, EQ-5D and
EQ-5D VAS score were found to be statistically lower, which shows us the presence of a relationship between the EQ-5D scale and accompanying diseases.

In lung cancer patients, besides clinical efficiency, health related effects on the quality of life and costs are also considered while making decisions for treatment. Patients with lung cancer have bad prognosis and the 5 year survival rates vary between 6 and $18 \%$. Treatments given could usually bring about additional problems for patients. It is stated that the EQ-5D scale accurately reflects the quality of life in lung cancer patients who have a prolonged survival. ${ }^{11}$ In our study, while pretreatment EQ-5D score decreased statistically after treatment, while EQ-5D VAS score did not change. It was also observed that EQ-5D and EQ-5D VAS score increased after treatment in SCLC patients while decreasing in NSCLC patients. The change in EQ-5D and EQ-5D VAS scores with treatment was found to affect survival at a significant rate.

In one study examining the use of EQ-5D in NSCLC patients in the British society, Doyle et al. reported that EQ-5D was not affected by age, gender and the overall quality of life scale but that it was affected by treatment response and disease related symptoms. ${ }^{12}$ EQ-5D may also be used to evaluate the effect of a chemotherapy regimen on quality of life of patients. ${ }^{13}$ In our study, since EQ5D and EQ-5D VAS in lung cancer patients over 70 years were found to be statistically low, a correlation was revealed between these scales and age. EQ-5D change was found to have no correlation with age, gender, smoking, tumor stage, treatment type, accompanying diseases and treatment response. However, cell type, ECOG and Karnofsky score change affected EQ-5D score significantly. It was determined that EQ-5D VAS score change was affected by smoking, ECOG and Karnosfky score change while other factors had no effect.

According to the evaluation by tumor cell type and tumor stage, EQ-5D VAS score varied significantly. The further the stage was, the lower the EQ-5D VAS score got. On the other hand, EQ-5D score showed no significant difference by tumor cell type and tumor stage. It was seen that EQ-5D and EQ-5D VAS score did not differ significantly 
following the treatment in patients with adenocarcinoma while significantly decreasing in squamous cell carcinoma. In a study carried out with 95 patients with NSCLC, the presence of metastasis was reported as a factor which apparently affects EQ5D and EQ-5D VAS measures. Both were found to be low in patients with metastasis. ${ }^{14}$ In a series of 263 patients; HRQOL, as measured by the EQ$5 \mathrm{D}$ domains, and utility were lower in patients with progressive disease when compared with progression free patients. There was a substantial impact of lung cancer on patients' HRQOL, with stage IV disease, line of treatment, and progressive disease, resulting in considerable deterioration of utility. ${ }^{15}$ Analyzing patients according to their stages in our study, it was found that EQ-5D and EQ-5D VAS values in stage IV patients were significantly lower in comparison with other stages.

EQ-5D measure at diagnosis was found to be moderately reliable, while the measure at the 3rd CT cycle, the one at the 5th CT cycle and those after the RT were highly reliable. In the evaluation of the sub-dimensions of EQ-5D according to internal consistency analysis, the items were found to be self-consistent. The results of the evaluations of EQ-5D VAS at diagnosis, the 3rd cycle, the 5th cycle and following the RT were found to be correlated with each other. Moreover, as our study design meets the requirements of 6 fit indices, EQ-5D was found to be valid.

Limitations included, the absance of quality of life assessment in the follow period (progression etc.).

Since no study has been carried out on the reliability, validity and internal consistency analyses of EQ-5D and EQ-5D VAS scales in patients with lung cancer in Turkey, our study is the first study to carry out these analyses. As the patients included in the study were gathered from 5 medical centers that frequently accept lung cancer patients, it has a large patient population. EQ-5D and EQ-5D VAS score are correlated with ECOG and Karnofsky performance measures, they reflect the patient's quality of life after treatment accurately and are useful in revealing survival.

In conclusion, it has been revealed with the present study that psychometric features of the Turkish version of the EQ-5D generic quality of life questionnaire are reliable and valid for lung cancer patients in Turkey and can safely be used in clinics.

\section{Acknowledgement:}

The authors would like to thanks and express our gratitude to Turkish Thoracic Society and Turkish Society for Quality of Life Research (SAYKAD) for support and encouragement.

- Oral Presentation: Turkish Thoracic Society 16. Annual Congress, Antalya, TURKEY, SSO07, 2013.

- Poster Presentation: 23. ERS Annual Congress, Barcelona, SPAIN, P-4501, 966-7, 2013.

\section{REFERENCES}

1. The WHOQOL Group. The development of the World Health Organisation quality of life assessment instrument (the WHOQOL). In: Quality of Life Assessment: International Perspectives. Orley J, Kuyken W (eds). Springer Verlag, Heidelberg, 1994: 41-57.

2. The World Health Organization Quality of Life Assessment (WHOQOL): development and general psychometric properties. Soc Sci Med 46: 1569-85, 1998.

3. Stucki G, Kroeling P. Principles of rehabilitation. In: Rheumatology. Hochberg MC, Silman AJ, Smolen JS, Weinblatt ME, Weisman MH (eds). Mosby, Toronto, 2003: 517-530.

4. Juniper EF. How important is quality of life in pediatric asthma? Pediatr Pulmonol 15: 17-21, 1997.

5. Fries J, Singh G. The Hierarchy Of Patient Outcomes. Quality of Life and Pharmacoeconomics. In: Clinical Trials. 2nd edition. Lippincott-Raven Publishers, Philadelphia, 1996: 33.

6. Eser S, Göksel T, Erbaycu AE, et al. Comparison of generic and lung cancer-specific quality of life instruments for predictive ability of survival in patients with advanced lung cancer. Springerplus 5: 1833, 2016.

7. Drummond MF, O'Brien BJ, Stoddart GL, Torrance GW. Methods for the Economic Evaluation of Health Care Programmes. York, Oxford University Press, 1997: 221-224.

8. Dolan P, Gudex C, Kind P, Williams A. The time trade-off method: results from a general population study. Health Econ 5: 141-154, 1996.

9. Pickard AS, Neary MP, Cella D. Estimation of minimally important differences in EQ-5D utility and VAS scores in cancer. Health Qual Life Outcomes 21: 70, 2007.

10. Kim SH, Kim HJ, Lee SI, Jo MW. Comparing the psychometric properties of the EQ-5D-3L and EQ-5D-5L in cancer patients in Korea. Qual Life Res 21: 1065-1073, 2012. 
International Journal of Hematology and Oncology

11. Grutters JP, Joore MA, Wiegman EM, et al. Health-related quality of life in patients surviving non-small cell lung cancer. Thorax 65: 903-7, 2010.

12. Doyle S, Lloyd A, Walker M. Health state utility scores in advanced non-small cell lung cancer. Lung Cancer 62: 374380, 2008.

13. Belani CP, Pereira JR, von Pawel J, et al. TAX 326 study group: Effect of chemotherapy for advanced non-small cell lung cancer on patients' quality of life - a randomized controlled trial. Lung Cancer 53: 231-239, 2006.

14. Trippoli S, Vaiani M, Lucioni C, Messori A. Quality of life and utility in patients with non-small cell lung cancer. Quality-of-life Study Group of the Master 2 Project in Pharmacoeconomics. Pharmacoeconomics 19: 855-863, 2001.

15. Chouaid C, Agulnik J, Goker E, et al. Health-related quality of life and utility in patients with advanced non-small cell lung cancer. J Thorac Oncol 8: 997-1003, 2013.

\section{Correspondence:}

Dr. Ahmet Emin ERBAYCU

Izmir Gogus Hastaliklari Hastanesi

Gögüs Hastaliklari Klinigi

Yenisehir, IZMIR / TURKEY

Tel: (+90-505) 5815631

Fax: (+90-232) 4587262

e-mail: afumetsu67@gmail.com 